\title{
FULL FAITH AND CREDIT TO STATUTES: THE DEFENSE OF PUBLIC POLICY
}

\author{
WILIIS L. M. REESE*
}

MHE MAJOR AREA OF UNCERTAINTY in the field of full faith and credit involves the extraterritorial effect that must be accorded 1 the statutes of sister states. The clause itself makes no distincFaith and Credit shall be given in each State to the public Acts, Records and judicial Proceedings of every other State." Such a distinction, however, was sharply drawn by the original statute passed in implementation of the clause; whereas it provided expressly that judgments should enjoy "such faith and credit . . . as they have ... in the courts of the State ... from which they are taken," it was silent with respect to the measure of credit owing to statutes. ${ }^{3}$ In the absence of any documentary evidence on the point, ${ }^{4}$ it is at least plausible to attribute the latter omission to a realization on the part of Congress that the problem of full faith and credit to statutes involved many unexplored complexities and to a consequent belief that the field was not yet ripe for legislative action but rather should be left to the courts to be worked out on a case-to-case basis.

What has been suggested above may be made clearer by a brief exposition of why the problems presented by statutes are more complex than those encountered in the case of judgments. The principal reason is simply the fact that normally there is but one judgment to be reckoned with, and the rare case of competing judgments can be disposed of with relative ease by according enforcement to that which was rendered last in point of time..$^{5}$ As such, the law relating to foreign judgments revolves largely around defenses against their enforcement, an area which is sufficiently

* Professor of Law, Columbia University.

I See generally, Jackson, Full Faith and Credit-The Lawyer's Clause of the Constitution, 45 Col. L. Rev. I (I945).

3 U.S. Const. Art. $4 \S I$.

3 I Stat. I22 (I790), 2 Stat. 298 ( $(804)$ ), Rev. Stat. $\$ 905$ at I7I ( 2 d ed., I875).

4 The only reference to the question in the available records of the Constitutional Convention is the statement that "Mr. Wilson and Docr. Johnson supposed the meaning to be that Judgments in one State should be the ground of actions in other States, and that acts of the Legislatures should be included, for the sake of Acts of insolvency." 2 Records of the Federal Convention 447 (Farrand ed., I9II).

5 Treinies v. Sunshine Mining Co., 308 U.S. 66 (r939); Rest., Judgments $\$ 42$ (I942). 
precise and definite to lend itself readily to legislative rule making. At the time of the implementing statute's enactment, the enforcement of foreign judgments had already become a common practice in AngloAmerican jurisprudence. ${ }^{6}$ Therefore, it involved only a small break with the past to put the enforcement of sister state judgments on a mandatory basis. More important still for our purposes, this step, in the light of past experience with foreign judgments, was one whose results and repercussions could in large part be envisaged in advance. After all, assuming that a given judgment had been rendered at a fair trial and by a court with jurisdiction over the parties and after proper notice to them, why should it not be enforced as of right in another state? To be sure, situations could be expected to arise where such enforcement would run counter to the interests and policies of the second state, ${ }^{7}$ but should not such occasional inconveniences be overborne by the strong unifying principle embodied in the full faith and credit clause, which was designed to further the needs of a unified, albeit federal, nation? ${ }^{8}$ So, at least, it may have seemed to the framers of the statute.

Quite different in this regard was the situation presented by sister state statutes. Here, problems involving choice of law would be met at each turn, for, in every case with contacts in two or more states, decision must first be made as to which one of the competing laws should properly be applied to govern the question at hand. Thus, any wholesale attempt to require application of sister state statutes would in effect place the entire field of choice of law upon a constitutional plane. Such a result, if it had been deemed desirable, could have been achieved in either one of two ways. First, the framers of the statute could have enacted a comprehensive set of choice of law rules which all of the courts, both state and federal alike, would have been obligated to follow. Such an ambitious program, if it had been attempted, would almost certainly have proved a failure for the very simple reason that a satisfactory statute cannot be drafted unless at least a majority of the problems involved in the field can be answered. And clearly, the framers of the implementing statute did not know the answers to all the problems posed by choice of law, for even with the benefit of a century and a half of further experience we do not know them now. What provisions, for example, should a statute seeking to regulate 265 .

${ }^{6}$ Page, Full Faith and Credit: The Discarded Constitutional Provision, [1948] Wis. I. Rev.

${ }^{7}$ Cf. Fauntleroy v. Lum, 2ro U.S. 230 (rgo8).

${ }^{8}$ See Hughes v. Fetter, 34 I U.S. 609, 6rI (r95I); Magnolia Petroleum Co. v. Hunt, 320 U.S. 430, 439 (I943); Milwaukee County v. White Co., 296 U.S. 268, 277 (I935). 
choice of law in the field of contracts contain? All that we know with certainty is that it is impossible to govern the entire field by a single rule, and to say, for example, that all questions of validity should be governed by the law of the place of making, or by that of the place of performance, etc. What is clearly required is a series of narrower rules, tailor-made to fit the many different types of contracts as well as the multitude of diverse problems that may arise in connection with each. But, with minor exceptions, ${ }^{9}$ the present state of our knowledge is simply not sufficient to tell us what the content of these narrower rules should be. In other words, the field of choice of law with respect to contracts is not yet ripe for legislative action. And, for similar reasons, the same is probably also true of all other aspects of choice of law, as, for example, those relating to torts, property interests, domestic relations, corporations, etc.

Alternatively, the framers of the implementing statute could have drafted some general formula which made clear that rules relating to the extraterritorial application of sister state statutes (i.e., choice of law rules) came within the constitutional domain, but which made no attempt whatsoever to state what the content of these rules should be. By this means, Congress would in effect have placed upon the Supreme Court the duty of drawing a comprehensive set of choice of law rules for the country at large. This solution would have avoided the difficulties inherent in drafting legislation in an informational vacuum; it would not, however, have been without its disadvantages. First of all, it would have imposed a heavy burden on the Supreme Court which would have been obliged to hear at least a substantial portion of the choice of law cases arising throughout the nation. Secondly, although the Court would have the advantage of deciding problems only as they arose, it too would suffer from the general dearth of information on the subject and hence would almost inevitably render decisions that would prove erroneous in the course of time. And such decisions, since they would be binding on state and lower federal courts alike, might have unfortunate consequences until they were overruled.

There is, of course, no way of telling whether these difficulties were in the minds of the framers of the implementing statute, and, if so, whether such difficulties caused them to remain silent with respect to statutes. At any rate, the fact that these difficulties do in fact exist is manifested by the vacillations of the Supreme Court in wrestling with the subject.

- For example, the courts are in general agreement that an alternative reference rule should be used to sustain the validity of a contract against the defense of usury. Cheatham, Goodrich, Griswold and Reese, Cases and Materials on Conflict of Laws 47r-77 (3d ed., I95 r). 
Roughly speaking, the decisions of the Court in this area may be said to fall within two categories, the one negative, and the other positive: (I) those which forbid a state from applying its own local law to a transaction because of the demands of the due process clause of the Fourteenth Amendment, and (2) those which compel a state to apply another's law on the ground of full faith and credit. At first, the Court tended to lay down strict rules on the subject. Thus, in the insurance field, it was held a viólation of due process for a state, other than that where the contract of insurance was technically made, to apply its own law to determine the rights of the insured under the policy. ${ }^{\circ}$ Conversely, full faith and credit was held to require application, in the case of fraternal benefit associations, of the law of the state of incorporation ${ }^{\text {II }}$ and, in the case of workmen's compensation, of the law of the place where the contract of employment was entered into, so long, at least, as that law purported to provide an exclusive remedy. ${ }^{\mathrm{Iz}}$ The Court has persistently adhered to its original position so far as fraternal benefit associations are concerned, ${ }^{13}$ but otherwise all else has been changed. Due process no longer forbids a state from applying its own law unless it has no reasonable contact with the transaction, ${ }^{\mathrm{T}}$ and, where such a reasonable contact exists, full faith and credit does not compel a state to apply another's law in preference to its own. ${ }^{15}$ In other words, further experience with the subject has induced the Court to withdraw almost entirely from the field of choice of law.

Another situation, divorced from the complexity of choice of law, may also be said to fall within the second (positive) category of decisions. In Broderick v. Rosner, ${ }^{16}$ suit was brought in New Jersey by the New York Superintendent of Banks against certain stockholders of an insolvent bank to recover their statutory liability. The complaint was originally dismissed by the state court because under New Jersey law such an action would not lie unless all of the corporation's creditors and all of its stockholders were joined as parties. This action, however, was reversed by the

${ }_{10}$ Mutual Life Ins. Co. v. Liebing, 259 U.S. 209 (1922); New York Life Ins. Co. v. Dodge, 246 U.S. 357 (r9I8).

Ix Modern Woodmen v. Mixer, 267 U.S. 544 (I925); Royal Arcanum v. Green, 237 U.S. 53 I (IgI5).

12 Bradford Electric Light Co. v. Clapper, 286 U.S. 445 (1932).

${ }_{3}$ Order of Commercial Travelers v. Wolfe, 33 I U.S. 586 (I947).

${ }_{4}$ Hoopeston Canning Co. v. Cullen, $3^{\text {I8 U.S. }} 3^{\text {I3 }}$ (I942); Home Ins. Co. v. Dick, 281 U.S. 397 (1930).

ss Pacific Ins. Co. v. Comm'n, 306 U.S. 493 (r939); Alaska Packers Ass'n v Comm'n, 294 U.S. 532 (1935).

${ }^{16} 294$ U.S. 629 (I935). 
Supreme Court as a violation of full faith and credit, because the New Jersey statute imposed "a condition, which, as here applied, is impossible of fulfillment"17 and a state "may not, under the guise of merely affecting the remedy, deny the enforcement of claims within the protection of the full faith and credit clause, when its courts have general jurisdiction of the subject matter and the parties." ${ }^{18}$ This case, of course, did not present any problem of choice of law, since New Jersey was not seeking to apply its own law to the transaction. It was merely refusing to entertain in its courts suit upon what was admittedly a New York cause of action; this, the Supreme Court held, it could not do.

A further source of complication has now entered upon the scene. As part of the I 948 revision to the Judicial Code, the implementing statute was amended so as to provide that both statutes and judgments alike should be accorded the "same full faith and credit" throughout the country "as they have ... in the courts of such State ... from which they are taken." W9 What, if anything, was intended to be accomplished by this amendment is by no means clear, since, so far as appears, it was enacted by Congress without discussion and the Revisers' Notes state simply that it "follows the language" of the full faith and credit clause itself. $^{20}$ Taken literally, however, the amendment would seem to constitute a clear mandate that the Supreme Court should henceforth interject itself more forcibly into the field of choice of law. Will the Court, however, feel obligated to assume such a task in view of the uncertainty as to the amendment's purpose? This, undoubtedly, is the most crucial question in the field of full faith and credit today.

The Supreme Court's recent decision in Hughes v. Fetter ${ }^{2 x}$ does little to clarify the problem; indeed Justice Black states explicitly in his majority opinion that it was found "unnecessary to rely on any changes accomplished by the Judicial Code revision." ${ }_{22}$ The decision is important, however, for two reasons. First, the case involves a situation in the realm of statutes which appears eminently suited for a hard-and-fast rule of full faith and credit. Second, the fact that four Justices dissented provides at least some indication that the present Court is unlikely to depart far from its present position of self-abnegation so far as the question of full faith and credit to statutes is concerned.

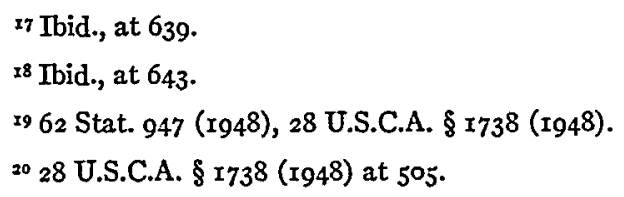


The facts of the case were these: The decedent, one Harold Hughes, was killed in an automobile accident in Illinois as the result of the alleged negligence of the defendant, Fetter. Suit, based upon the Mllinois wrongful death statute, was thereupon brought in a Wisconsin state court by plaintiff, Hughes' administrator, against Fetter and his insurance company. It appeared that both of the individual parties were residents of Wisconsin, that the defendant insurance company was incorporated in that state, and that the decedent, Hughes, had likewise been residing there at the time of his death. Upon motion of the defendants, the trial court dismissed the complaint on the merits, because in its view the Wisconsin statute, by creating a right of action only for deaths caused in that state, evinced a public policy against the entertainment of suits brought under the wrongful death acts of other states. This action was affirmed by the Wisconsin Supreme Court, ${ }^{23}$ and the case was then taken on appeal to the Supreme Court of the United States, which reversed with, as has already been noted, four Justices dissenting.

In the course of his majority opinion, Justice Black stated that "full faith and credit does not automatically compel a forum state to subordinate its own statutory policy" to that of another state; "rather, it is for this Court to choose in each case between the competing public policies involved." ${ }_{24}$ He noted, however, that, since Wisconsin was not seeking to apply its own wrongful death statute, instead of that of Illinois, "to measure the substantive rights involved," 25 the "narrow question" presented was simply whether Wisconsin "can close the doors of its courts to the cause of action created by . . Illinois. . . ."26 In short, the "basic conflict" involved was not between the public policies of two or more states, but between that of Wisconsin and "the strong unifying principle embodied in the Full Faith and Credit Clause looking toward maximum enforcement in each state of the obligations or rights created or recognized by the statutes of sister states." In these circumstances, it was held that "Wisconsin's policy must give way." Since Wisconsin had a wrongful death statute of its own, it could have "no real feeling of antagonism against wrongful death suits in general." ${ }^{27}$ Also, "relevant, although not crucial here" was the fact that, while in the present case jurisdiction over at least the individual defendant could apparently have been obtained in Illinois by substituted service, "in other cases Wisconsin's exclusionary statute

${ }^{23} 257$ Wis. 35,42 N.W. $2 \mathrm{~d} 45^{2}$ (1950).

24 Hughes v. Fetter, 34I U.S. 609, 6II (I95I).

${ }^{26}$ Ibid., at 6II.

25 Ibid., at 6 I2 n. Io.

27 Ibid., at 612 . 
might amount to a deprivation of all opportunity to enforce valid death claims created by another state." 28

The dissent, written by Justice Frankfurter and concurred in by Justices Reed, Jackson and Minton, asserted that the "dominant" concern of the states in the local administration of law "should not be sacrificed in the interest of a merely literal reading of the Full Faith and Credit Clause." 29 Although it was admitted that "[i]n the field of commercial law-where certainty is of high importance," 30 deference had at times been required either to the law of the state of incorporation or to that of the place of contract, it was said that in tort actions, where there is no similar need for the predictibility of ultimate consequences, "there is little reason to impose a 'state of vassalage' on the forum." ${ }^{3 x}$ As such, the action of the Wisconsin courts should not be reversed so long as there was a "reasonable basis" for that state to close its courts to the Illinois cause of action. Such a reasonable basis was said to be provided by the difficulty of applying a foreign statute whose details might differ widely from that existing at the forum. "The [Wisconsin] legislature may well feel that it is better to allow the courts of the State where the accident occurred to construe and apply its own statute, and that the exceptional case where the defendant cannot be served in the State where the accident occurred does not warrant a general statute allowing suit in the Wisconsin courts." 32

In many respects, the most surprising thing about the case is the number of Justices who joined in the dissent. It will be noted that, whereas the majority found it possible to reach their decision without reliance upon the recent amendment to the implementing statute, the minority, although they did not in terms refer to the amendment, must obviously have thought that even its sweeping language did not govern a case scarcely distinguishable on its facts from the Supreme Court's earlier holding in Broderick ข. Rosner. ${ }^{33}$ As such, it is difficult to avoid the conclusion that, in spite of the amendment, a substantial minority of the Court will prove unwilling to extend further the scope of full faith and credit with respect to statutes.

One further aspect of the decision deserves mention. Wisconsin was not here trying to apply its own law to the transaction; therefore the case was not concerned with the impact of full faith and credit upon the complexities of choice of law. Nor was the refusal of the Wisconsin court to

$$
\begin{aligned}
& { }^{28} \mathrm{Ibid} \text {, at } 613 \text {. } \\
& 29 \text { Ibid., at } 620 \text {. } \\
& 3^{3} \mathrm{Ibid} . \text { at } 615 \text {. } \\
& { }^{3} \text { Ibid., at } 67 \text {. } \\
& { }^{2} \text { Tbid., at 6rg. } \\
& 33294 \text { U.S. } 629 \text { (1935). }
\end{aligned}
$$


entertain the suit based upon the doctrine of forum non conveniens or upon the ground that Illinois law provided a peculiar remedy which they themselves would be unable to grant. The only question presented was whether, on the ground of public policy, a state can close its courts to a cause of action arising under the laws of a sister state. It is seriously questioned whether this should ever be permissible.

A hard-and-fast rule requiring the states to entertain sister state causes of action would certainly further the central purpose of the Full Faith and Credit clause, which was to "alter the status of the several states as independent foreign sovereignties ... and to make them integral parts of a single nation throughout which a remedy upon a just obligation might be demanded as of right, irrespective of the state of its origin." 34 Such a proposed rule would operate in a narrow area, totally free from any complexities posed by choice of law, and, moreover, would be one whose results and repercussions could clearly be envisaged beforehand. For it is now firmly established that full faith and credit requires the enforcement of a sister state judgment even though that judgment was based upon a cause of action utterly repugnant to the forum's law. ${ }^{35}$ The principle underlying this latter rule seems equally applicable to the field of statutes: To be sure, entertainment of a sister state cause of action, in contrast to the enforcement of a judgment, does require the forum court to apply the law of another jurisdiction. But this burden is only one of the costs of a federal system; to say, as the minority would seem to suggest, that a state can escape its constitutional obligations on this ground means simply that, so far as statutes are concerned, the Full Faith and Credit clause is dead.

${ }^{34}$ Justice Stone in Milwaukee County v. White Co., 296 U.S. 268, at 277 (1935).

35 Fauntleroy v. Lum, 210 U.S. 230 (Igo8). 